\title{
Healthy Vertical Housing Study of Psychological Considerations
}

\author{
Lubna A. Kadhim*, Mufeed Ehsan Shok \\ Department of Architectures, University of Technology, Baghdad, Iraq
}

Received June 20, 2021; Revised September 24, 2021; Accepted October 17, 2021

\begin{abstract}
Cite This Paper in the following Citation Styles
(a): [1] Lubna A. Kadhim, Mufeed Ehsan Shok, "Healthy Vertical Housing Study of Psychological Considerations," Civil Engineering and Architecture, Vol. 9, No. 7, pp. 2187-2195, 2021. DOI: 10.13189/cea.2021.090708.
\end{abstract}

(b): Lubna A. Kadhim, Mufeed Ehsan Shok (2021). Healthy Vertical Housing Study of Psychological Considerations. Civil Engineering and Architecture, 9(7), 2187-2195. DOI: 10.13189/cea.2021.090708.

Copyright $\bigcirc 2021$ by authors, all rights reserved. Authors agree that this article remains permanently open access under the terms of the Creative Commons Attribution License 4.0 International License

\begin{abstract}
The world population is growing significantly, and the population continues to flow from the countryside to the cities. Such phenomena make vertical housing a solution to these issues even if it is not as satisfactory as other forms of accommodation. The overview indicates that some adverse psychosocial effects have been consistently associated with elevated residential environments. The research problem has been identified. The effects of vertical housing on mental health and how these psychological effects can be reduced to create healthy vertical housing lack clarity. The research starts from a general hypothesis that vertical housing has adverse effects on the mental health of residents. Thus, the need lies in knowing the reasons for this effect and how to address it through design, thus creating healthy vertical residential buildings. The research adopted the descriptive analysis method based on the vocabulary of the theoretical framework extracted from previous proposals. The Interlace project in Singapore was chosen for the practical study after obtaining the title "the best building in the world" at the World Architecture Festival in 2015.
\end{abstract}

Keywords High-Rise Housing, Mental Health, Psychological Health, Social Connectivity, Vertical Housing

\section{Introduction}

Housing is a place where one can live calmly and in prosperity and development. Housing is a place where people feel safe and enjoy privacy and which offers a sense of belonging. Thus, it is where individuals find themselves and meet their environmental, psychological, economic, and security needs [1]. Given the increasing demand for urban housing and the problem of expensive land prices, vertical housing has become one of the most appropriate and realistic solutions [2]. A vertical house can be defined as a group of homes built in a multi-story building, in a functionally arranged environment, horizontally and vertically, and equipped with components for common use [2][3]. It is a building with at least five floors and an elevator. Vertical dwellings can consist of towers of point blocks twenty or more stories high or slab blocks providing hundreds of meters of detached homes connected by long internal or external corridors [4]. Saleh (2020) defined housing as a building consisting of more than seven floors or a structure that requires elevators for reasonable use. He added that the perceived height of the building is a personal factor, which can depend on the respondent's past experiences, the general shape of the building, and the surrounding physical environment [5]. For many years, the residential environment has been considered an essential place that influences human health, physical or mental. Socio-environmental theories have identified various features of the built environment as stress generators that impact mental health and individual performance that can be strongly mitigated through environmental improvements. Socio-environmental approaches have been explored to integrate social, physical, cultural, and psychological aspects involving the behavior of individuals and the environment [6]. Therefore, the research was keen to guide the design of vertical housing that takes care of the psychological requirements, which affect health. Especially after the COVID-19 pandemic, 
the crisis made most of the world's population stay in their homes, and homes become the only place where people sleep, eat, work, exercise, and socialize [7]. Therefore, high residential buildings should be a place for living and feeling for residents. If buildings become just a container for living, we will be neglecting the psychological aspect and affect the mental health of the inhabitant [8]. The architects have designed high residential buildings to relieve people's stress and burden. The success of the construction depends partly on how much it facilitates the desired activities of its inhabitants. The high-score structures effectively relieve "life stresses," whereas lower-level structures are either unable to relieve stress significantly or may contribute to it. Sociologists have long been interested in the relationship between housing and people's health, attitudes, and behavior [9]. The member states of the United Nations have also described housing as a structure that offers the following: adequate shelter, which means more than one roof over the head; adequate privacy; sufficient space, physical accessibility, adequate security, and security of tenure; structural stability and durability; proper lighting, heating, and ventilation; adequate basic infrastructure, such as water supply, sanitation, and waste management facilities; appropriate environmental quality and health-related factors; convenient and accessible location for business and basic amenities; available at a reasonable cost. Suitability often varies from country to country because it depends on specific cultural, social, environmental, and economic factors [10]. Therefore, this study's general objective is to consider the needs of the inhabitant, including mental health, when designing vertical residential buildings and thus creating healthy vertical housing.

\section{Literature Review}

\subsection{Housing and Mental Health [11]}

The study identified the living environment as a place where people usually spend most of their time because it is where they communicate with the most important members of their social network. This article explores the relationship between housing and mental health [P: 476]. Different housing characteristics can affect mental health. The types of housing are single housing, multiple housing units, low-rise buildings, and tall buildings. Ground-level housing quality is ideal for the well-being of children and offers overall housing quality, including structural quality and maintenance [P: 475]. The research results showed that residents of vertical residential buildings were more likely to go to a psychiatric clinic. Women who live in a vertical apartment building have complained of depression and loneliness more than those in separate households. Apartment dwellers in the area are less happy, less healthy, and less desirable. They complain more about isolation. Residents of vertical apartment buildings found their social support and activities with other residents decreased. Such buildings contribute to depression, a higher incidence of mental illness, more isolation in society, and more restrictions on children's play because children are more likely to play alone. The study concludes the following [495]:

- Quality housing is essential for mental health.

- Multi-family vertical houses are not suitable for families with preschool children because of two factors: (a) the mother's social isolation and (b) the lack of opportunities for children to play .

- Particular attention should be given to spaces to support lively and informal communication with other residents and child-friendly places for play.

- Providing spaces where children can escape crowding and other chaotic living conditions are needed.

- The design and planning must be improved by analyzing housing units, residential buildings, and neighborhoods. Table 1 show the most important vocabulary extracted from the study.

Table 1. Most important vocabulary of a study of Gary et al. (2003)

\begin{tabular}{|c|c|c|c|c|c|}
\hline \multirow{6}{*}{$\begin{array}{c}\text { The relation } \\
\text { between mental } \\
\text { health and housing }\end{array}$} & \multirow{3}{*}{ Housing Type } & \multirow{2}{*}{$\begin{array}{l}\text { Multi } \\
\text { stories }\end{array}$} & $\begin{array}{l}\text { More likely to go to } \\
\text { psychiatric clinics }\end{array}$ & \multicolumn{2}{|c|}{ Social isolation } \\
\hline & & & $\begin{array}{l}\text { Less likely to go to psychiatric } \\
\text { clinics }\end{array}$ & \multicolumn{2}{|c|}{ Insufficient play for children } \\
\hline & & Single & \multirow{4}{*}{ Social preferences } & \multicolumn{2}{|c|}{$\begin{array}{l}\text { Special attention to pool spaces to support } \\
\text { adjacent communication }\end{array}$} \\
\hline & \multirow{3}{*}{\multicolumn{2}{|c|}{ Overall quality of the dwelling }} & & $\begin{array}{l}\text { Improved the } \\
\text { design and } \\
\text { planning }\end{array}$ & $\begin{array}{l}\text { The neighborhood, } \\
\text { the building, the } \\
\text { housing unit }\end{array}$ \\
\hline & & & & \multicolumn{2}{|c|}{ Reduced noise } \\
\hline & & & & \multicolumn{2}{|c|}{ Increased social interaction } \\
\hline
\end{tabular}




\subsection{Inadequate Housing and Health [10]}

The study addressed the importance of housing conditions as a major factor affecting health. The study concluded that the living environment impacts health through the quality of urban and architectural design [P: 411]. Poorly planned or degraded living environments often lack public services, green spaces, parks, playgrounds, and walking areas, leading to lack of physical exercise, increased obesity, cognitive problems in children, and loss of athletic ability and social contact, thus affecting physical and mental health. The study puts forward three determinants of access to healthy housing.

- Ease of access: Entering a building, home, or environment is not enough for a person. Regardless of age or financial situation, one must make full use of the building and living environment [P:425].

- Lack of residential environments (sports facilities, playgrounds, parks, or other open spaces) and restrictions on walking or cycling, lack of sidewalks/biking paths, low connectivity, and unattractive exterior design are important determinants of fitness [P:414].

- Noise: Noise exposure is a major cause of inconvenience and reduced quality of life because it affects mental health and physical symptoms, such as migraine headaches and high blood pressure [P:421].

\subsection{Consequences of Living in High-Rise Buildings [12]}

High-rise buildings have been associated with many unpleasant consequences. Among the topics included in this study are dissatisfaction, fear, behavior problems, stress, bad social relationships, suicide, lack of help, disorders of child development, and poor mental health [P:2]. The study indicated that vertical housing raises some concerns, including the following [P: 3]:

- Residents themselves, their family member, or their neighbor would fall or jump from a high window.

- Some residents feared being trapped inside during a fire. Getting to the street from a tall building usually takes longer than it does for few-story dwellings.

This fear of strangers leads to fear of crimes and a lack of social support. The study concluded that one of the architectural reasons for these concerns is the shape of the building itself. Many non-architectural reasons have been identified. The most important reasons are the location of the building and the economic and social situation. Having young children and population density may increase the high population density of a building and improve social interaction [P:4]. As shown in Table 2, children in low-rise housing are better off because vertical housing either leaves them in the open air relatively unattended or limits their outdoor activities. Residents of tall buildings may have fewer friendships in buildings [P: 14]. Likewise, fear of crime is greater in tall buildings, controlled entrances reduce crime and fear [P: 4], and a small percentage of suicides are attributed to living in high buildings [P:14].

\subsection{Relationship between Crime and Dwelling Type [} 13]

The importance of housing in providing individuals with a sense of security in their area is preserved because insecurity is one of the most important causes of psychological instability, which affects personal health. However, whether all types of housing provide this sense of security in the same way is unclear. This article provides an analysis of the relationship between housing type and crime fear [P:365]. Newman also believes that, given the increased anonymity of building residents, residents of multi-family houses face greater fear of crime [P: 366]. The existence of social connections acts as an intermediary between the type of construction and the fear of crime [P:374]. The results of this analysis show that people living in high-rise and low-rise apartments are less likely to be afraid of crimes in their own homes compared with residents living in independent single-family homes. The most interesting finding from this analysis is that apartment living can reduce potential fear when you are alone at night. One possible explanation for these results is the fortress effect: high-rise buildings isolate individuals in physical spaces, provide security for apartments, and maintain physical and social distance from the rest of the community. If apartment residents actually "strengthen" themselves at home [P: 365], they must consider the impact on the well-being of the neighborhood and community. More specifically, physical isolation from the community can also lead to social isolation. Green and Gilbertson pointed out that recent safety improvements in the tower have improved the sense of security in the home but may have a negative impact on residents' sense of community. However, reducing the strengthening effect of high-rise residential buildings is possible. For example, some studies have shown that integration into nature in a high environment positively encourages social interaction between neighbors [P:378].

Table 2. Vocabulary extracted from the study of Gifford (2011)

\begin{tabular}{|c|c|c|c|c|}
\hline \multirow{5}{*}{$\begin{array}{l}\text { Consequences of living } \\
\text { in tall buildings }\end{array}$} & Fear & \multirow{5}{*}{$\begin{array}{l}\text { Causes of } \\
\text { concerns }\end{array}$} & \multirow{3}{*}{ Architecture } & \multirow{3}{*}{$\begin{array}{c}\text { Building shape } \\
\text { Site }\end{array}$} \\
\hline & Stress & & & \\
\hline & Suicide & & & \\
\hline & Bad social relationships & & \multirow{2}{*}{ Non-architectural } & Economic situation \\
\hline & Dissatisfaction & & & Population density \\
\hline
\end{tabular}




\subsection{Social Interaction and Third Space Relationship in Vertical Housing in Malaysia [14]}

The study examined how to improve social interaction in vertical residential buildings in Malaysia, where social interaction plays a vital role in achieving social sustainability. Social sustainability has been largely ignored in general sustainability discussions; in contrast, economic and environmental sustainability has always been a top priority [P:3]. Interaction is important to maintain good physical and mental health. The development of children is greatly affected by social interaction because the child begins to develop his social skills and cognitive development through interaction with his family and peers. Children who live in high apartments show psychological pressure and have more learning difficulties than those in a low-rise building [P:3]. This study presents the design of three-dimensional space to ensure that children are provided with adequate social space. Vertical residential buildings usually provide common spaces on one level. The level of the shared space is usually located on the ground floor, the mezzanine of a building, and the sky court. A sky court restructures community and social areas by dividing them into several levels arranged in time periods of several residential levels. It can be defined in terms of spatial morphology or by breaking the mass. The potential monotony of repetitive floor slabs through the juxtaposition of mass and void, adding that sky court "is often located in the vicinity of buildings and usually consists of three or more floors to allow more ventilation and light to penetrate deeper into the structure, improving the internal environment" [P: 9].

\section{The Abstracted Theoretical Framework for Healthy Housing}

From the above Propositions, Determining the Abstract's Theoretical Framework for Healthy Housing is Possible According to Table 3.

Table 3. Abstracted theoretical framework for healthy housing

\begin{tabular}{|c|c|c|c|c|}
\hline Main singular & Secondary singular & \multicolumn{3}{|c|}{ Indications } \\
\hline \multirow{8}{*}{$\begin{array}{l}\text { Design quality } \\
\text { X1 }\end{array}$} & \multirow{8}{*}{$\begin{array}{l}\text { Social preferences } \\
\qquad \mathrm{X} 1-1\end{array}$} & \multicolumn{2}{|c|}{ Special attention to areas of assembly } & $(\mathrm{X} 1-1) 1$ \\
\hline & & \multicolumn{2}{|c|}{ Noise reduction } & $(\mathrm{X} 1-1) 2$ \\
\hline & & \multicolumn{2}{|c|}{ Increased social interaction } & $(\mathrm{X} 1-1) 3$ \\
\hline & & \multicolumn{2}{|c|}{ Increased sense of safety } & $(\mathrm{X} 1-1) 4$ \\
\hline & & \multicolumn{2}{|c|}{ Ease of access } & $(\mathrm{X} 1-1) 5$ \\
\hline & & \multirow{3}{*}{ Adequate green spaces } & Gardens & \multirow[t]{3}{*}{$(\mathrm{X} 1-1) 6$} \\
\hline & & & Playgrounds & \\
\hline & & & Walking areas & \\
\hline \multirow{11}{*}{$\begin{array}{l}\text { Reasons for fears } \\
\text { (dissatisfaction, poor social } \\
\text { relations, and stress) from living } \\
\text { in tall buildings } \\
\text { X2 }\end{array}$} & \multirow{2}{*}{$\begin{array}{l}\text { Shape of the building } \\
\qquad \mathrm{X} 2-1\end{array}$} & \multicolumn{2}{|c|}{$\begin{array}{l}\text { A shape that allows more gathering places and green } \\
\text { spaces }\end{array}$} & $(\mathrm{X} 2-1) 1$ \\
\hline & & \multicolumn{2}{|c|}{$\begin{array}{l}\text { A shape and pattern that provides adequate ventilation } \\
\text { and light }\end{array}$} & $(X 2-1) 2$ \\
\hline & \multirow{3}{*}{$\begin{array}{l}\text { Site } \\
\mathrm{X} 2-2\end{array}$} & \multicolumn{2}{|c|}{ Ease of access } & $(\mathrm{X} 2-2) 1$ \\
\hline & & \multicolumn{2}{|c|}{ Proximity to services } & $(\mathrm{X} 2-2) 2$ \\
\hline & & \multicolumn{2}{|c|}{ Places to play } & $(\mathrm{X} 2-2) 3$ \\
\hline & $\begin{array}{c}\text { Economic situation } \\
\text { X2-3 }\end{array}$ & \multicolumn{2}{|c|}{ Low-income residents } & $(X 2-3) 1$ \\
\hline & \multirow{5}{*}{$\begin{array}{l}\text { Safety } \\
\text { X2-4 }\end{array}$} & \multicolumn{2}{|c|}{ Creating eyes on the street } & $(\mathrm{X} 2-4) 1$ \\
\hline & & \multicolumn{2}{|c|}{ Sense of belonging } & $(\mathrm{X} 2-4) 2$ \\
\hline & & Strengthening of $\mathrm{n}$ & rly relations & $(X 2-4) 3$ \\
\hline & & $\begin{array}{r}\text { Increased sense of secur } \\
\text { developn }\end{array}$ & ugh technological & $(X 2-4) 4$ \\
\hline & & Emergency exits an & ance to them & $(X 2-4) 5$ \\
\hline \multirow{3}{*}{$\begin{array}{l}\text { Improving social interaction } \\
\text { X3 }\end{array}$} & \multirow{3}{*}{$\begin{array}{l}\text { Increase the community } \\
\text { space } \\
\text { X3-1 }\end{array}$} & Merging nature with & h environment & $(\mathrm{X} 3-1) 1$ \\
\hline & & Increased meeting are & de the building & $(\mathrm{X} 3-1) 2$ \\
\hline & & Providing g & aces & $(\mathrm{X} 3-1) 3$ \\
\hline \multirow{3}{*}{$\begin{array}{l}\text { Environmental aspects } \\
\qquad \mathrm{X} 4\end{array}$} & \multirow{3}{*}{$\begin{array}{l}\text { Ventilation and natural } \\
\text { lighting } \\
\text { X4-1 }\end{array}$} & Improved interr & ironment & $(\mathrm{X} 4-1) 1$ \\
\hline & & $\begin{array}{r}\text { Reduced cost of lightin } \\
\text { artificia }\end{array}$ & $\begin{array}{l}\text { onditioning, and } \\
\mathrm{g}\end{array}$ & $(\mathrm{X} 4-1) 2$ \\
\hline & & $\begin{array}{r}\text { Outdoor views reducing } \\
\text { mental }\end{array}$ & ssion, stress, and & $(\mathrm{X} 4-1) 3$ \\
\hline
\end{tabular}




\section{Methodology}

The research depends on the descriptive-analytical approach that refers to the vocabulary of the theoretical framework (Table 3) extracted from the studies submitted for accreditation in the case study analysis. The analysis process will be carried out accordingly. The first stage is the description of the general project. The second stage is the project's analysis according to the theoretical framework's vocabulary, measuring the extent of its achievement in the case of the study. The author fills in a checklist to test the feasibility of possible values for each of the items given in Table (3), where the realized value is indicated by the symbol (2), the partially realized value is indicated by the symbol (1), and the unrealized value is indicated by the symbol (0).

\subsection{Case Study - The Interlace, Singapore}

The Interlace is a large residential project in Singapore where Ole Scheeren was commissioned to design thousands of homes on an 8-hectare plot of land with a height of 25 floors or 80 meters in 2013. Interlace takes an unusual approach by not building stand-alone residential towers but inverting the high-rise towers and placing them on top of one another. Thus, the architect created several public and private outdoor areas. Opportunities for social interaction and shared activities, providing spaces for privacy and tranquility-promoting community awareness and protecting individuality and identity. [15] Figure 1 shows a perspective of the (The Interlace) residential project in Singapore.

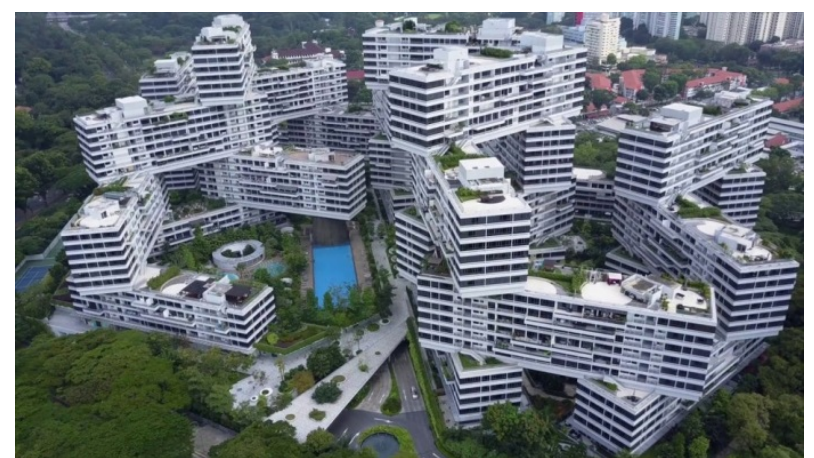

Figure 1. A perspective of the The Interlace residential project in Singapore [16]

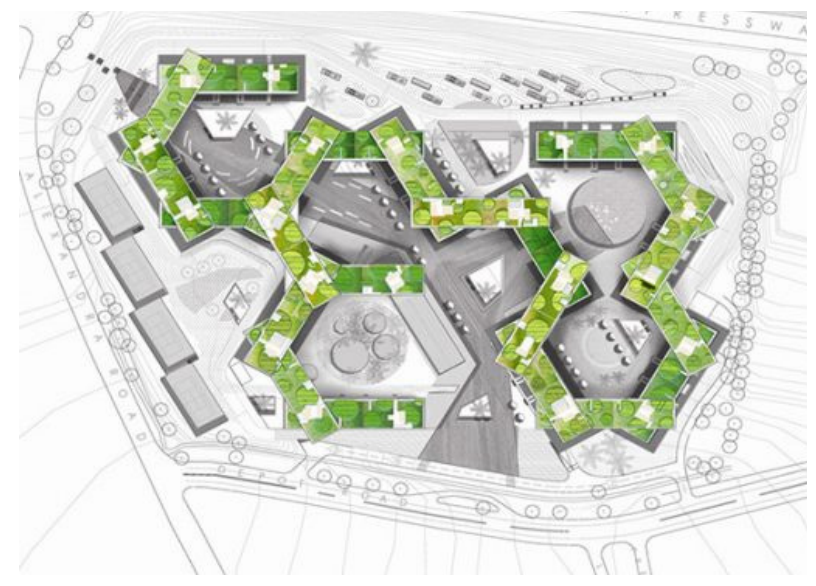

Figure 2. The hexagonal shapes and the eight assembly yards [16]

\section{Quality Design (X1)}

\section{- Social preferences $(\mathrm{X} 1-1)_{1-6}$}

The indicators specific to the singularity of paying special attention to gathering spaces and providing adequate green spaces have been achieved. The most striking feature is the outdoor area created by the hexagonal arrangement. The hexagon creates eight themed courtyards, providing space for community, sports, and family activities [13], allowing pedestrian traffic, light, and breezes to flow through one continuous park. Each space has a separate function and appearance, in addition to easy access to the project.

\section{Fear of Living in High Buildings (X2)}

- The shape of the building (X2-1) $)_{1-2}$

The formation of the building in the form of interlocking blocks creates a vertical village with terraced gardens (Figure 3). Through the stacking of apartments, the design generates the doubling of the horizontal surfaces inhabited by large rooftop gardens and landscaped terraces, which provides ventilation and natural lighting for all residential units, giving a feeling of comfort and relaxation [13]. Forming blocks in this way gives an intricate blank shape between the solid masses through which space flows. The gaps between the blocks become gates framing the views. 


\section{- Site $(\mathrm{X} 2-2)_{1-3}$}

Specific indicators of uniqueness were achieved through ease of access and the provision of multiple and clear entrances (Figure 5), in addition to the availability of services, and the provision of places for play, gathering, and relaxation (Figure 6).

\section{- Economic Status (X2-3)}

One of the basic principles of the project is providing affordable housing [19].

\section{- Safety (X2-4) $1-5$}

The indication of the singularity was achieved and represented by creating eyes on the street and the ability to observe children while playing through balconies. What distinguishes The Interlace from a distance is that it is not intended to break any technical barriers but is a space that creates a sense of community and belonging and enhances the sense of security [19], in addition to the use of modern technologies for monitoring.

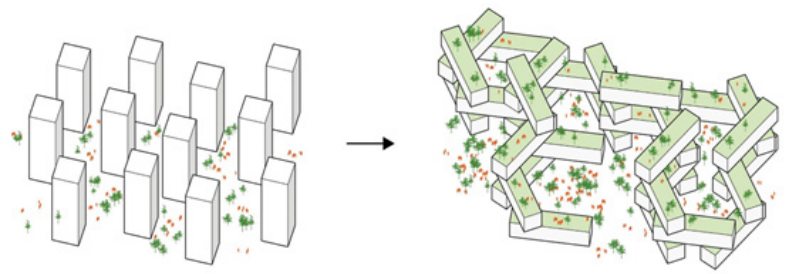

Figure 3. Building formation [18]

\section{Improving Social Interaction (X3)}

- Increasing the community space (X3-1) $)_{1-3}$

The specific indicators of the singularity of merging nature with the high environment have been achieved. The accumulation of residential buildings provides space for many rooftop gardens, multiplying the green spaces and social spaces. The Interlace enhances the interconnection of the community with the surrounding natural environment. The horizontal directions of the residential buildings, in addition to the large communal spaces, encourage interaction and shared experience, because the idea of community life is emphasized through extensive networks of gardens [17],

\section{Environmental Aspects (X4)}

- Ventilation and natural lighting (X4-1) $)_{1-3}$

Indices of singularity are achieved through mass and void in building formation. When the prevailing wind blows through the permeable courtyard, it first passes through the swimming pool or artificial lake, creating a cool climate while also benefiting from the best shade coverage provided by the building itself. The project also pays great attention to creating comfortable interior spaces with ventilation and natural lighting, which reduces the cost of lighting and artificial ventilation. Rooftop gardens and balconies (Figure 4) also contribute to a mild climate and reduce feelings of tension, aggression, and mental fatigue [16].

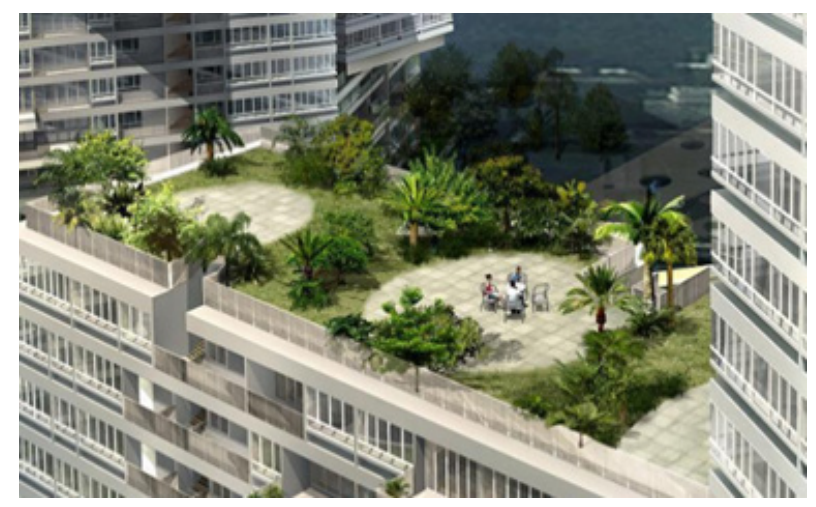

Figure 4. Rooftop gardens, terraces, and outdoors [18] 


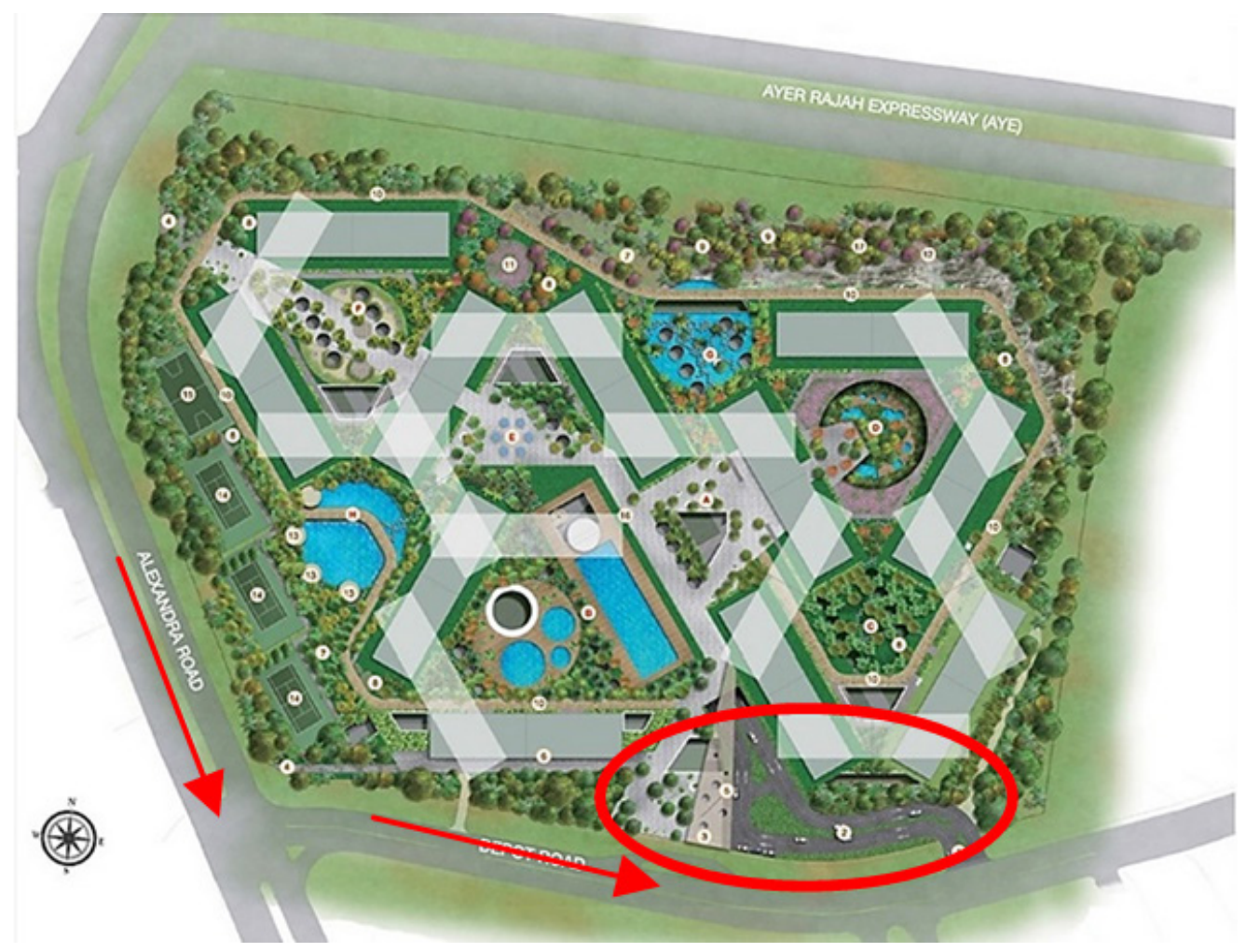

Figure 5. The main project entrances [18]

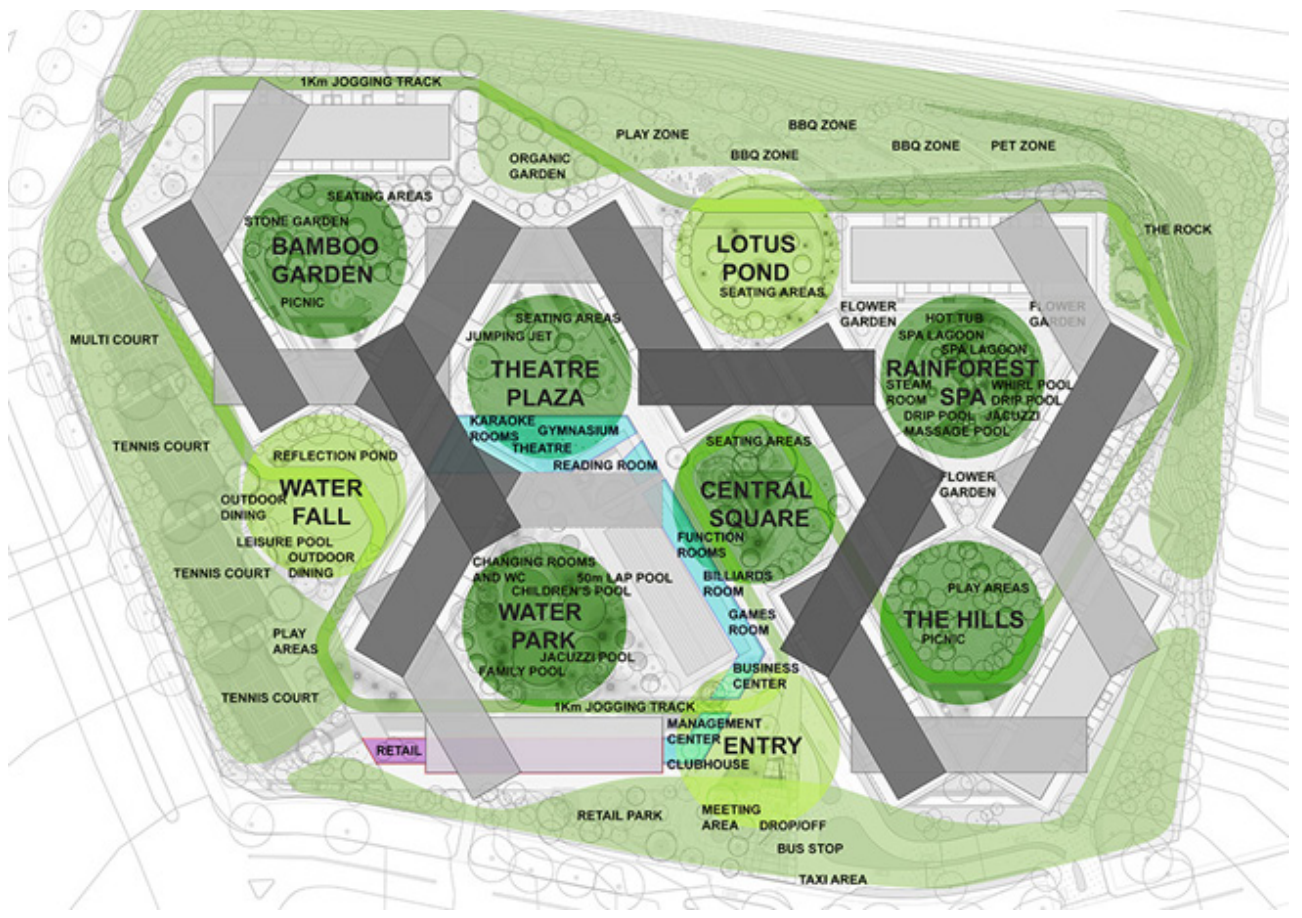

Figure 6. Places for play, gathering, and relaxation [16] 


\section{Results and Discussion}

The achievement of the global experience of the theoretical framework indicators extracted by marking the achieved value with the symbol (2) and the somewhat achieved value with the symbol (1) and the unrealized symbol (0) is verified.

5.1. The project achieved $70 \%$ of the first item (x1) indicators of the theoretical framework, and $30 \%$ were partially achieved, as shown in figure (7).

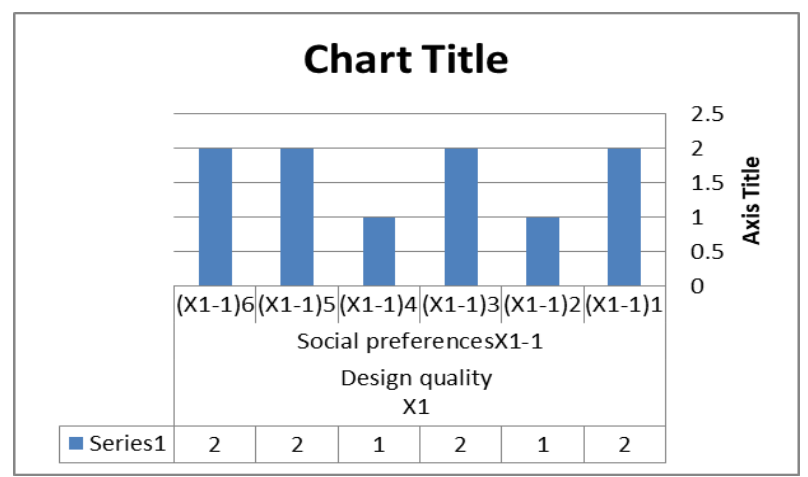

Figure 7. Results of the first item, "Quality of Design"

5.2. The project achieved $82 \%$ of the second item (X2) indicators of the theoretical framework, and $18 \%$ was partially achieved, as shown in Figure (8).

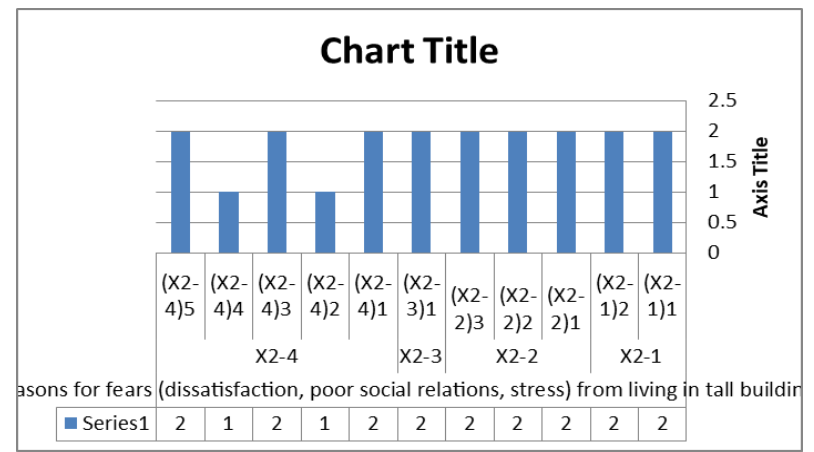

Figure 8. Results of the second item, "Reasons for fear of living in tall buildings"

5.3. The project achieved $100 \%$ of the third item (X3) indicators of the theoretical framework, as shown in Figure (9).

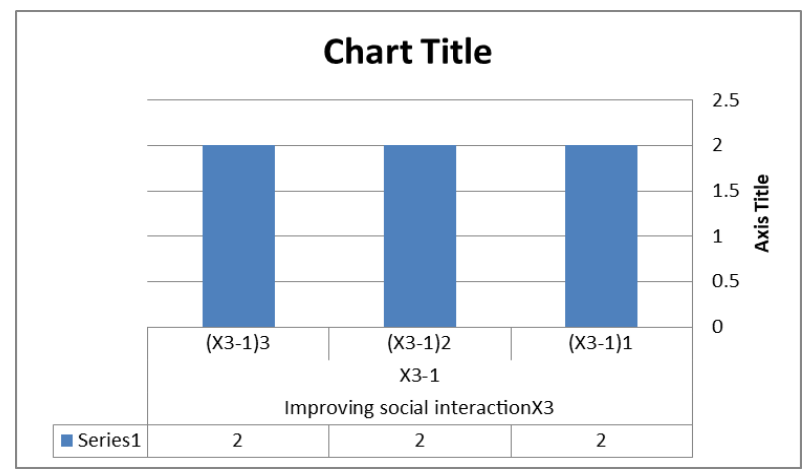

Figure 9. Results of the third item, "Improving Social Interaction"

\subsection{The Project Achieved $100 \%$ of the Fourth Item (X4) Indicators of the Theoretical Framework, as shown in Figure (10).}

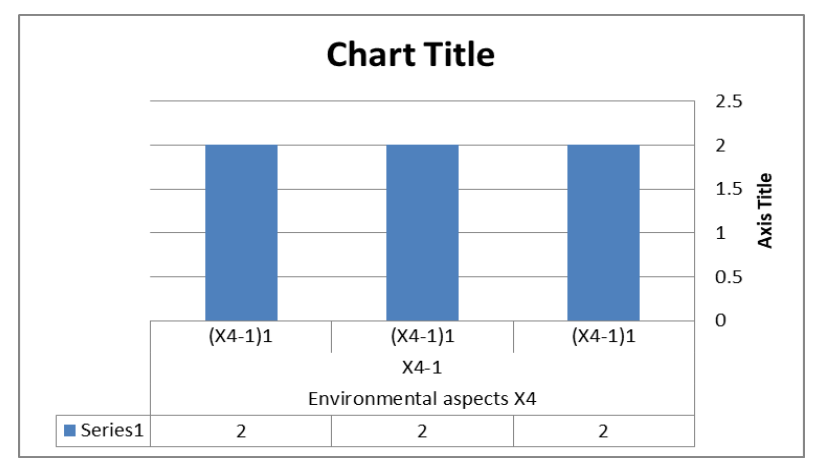

Figure 10. Results of the fourth item "Environmental Aspects"

\section{Conclusion and Recommendations}

Housing is a form of art and machinery. Architects design them to relieve the pressures of life and remove the burden from human shoulders. High residential buildings should not only be a container for living but also contain residents' feelings. If housing becomes just a container for living and we neglect its psychological aspect, it will affect residents' psychological and mental health. The proposals indicated a strong correlation between poor housing and symptoms of depression. The research results showed that the built environment is one of the main determinants of health, the quality of which depends on on-site planning, special attention to gathering places, increased opportunities for social interaction, noise reduction, and an increased sense of safety. The global project, The Interlace, Singapore achieved most of the indicators of the theoretical framework. It benefits from global experiences to create vertical housing that considers the mental health of the population.

The research recommends studying the needs of the population before embarking on the design of vertical residential buildings and moving toward designing healthy residential buildings that consider the mental and physical health aspect and benefiting from international experiences that focus on the social aspect to improve the mental health of the population and make vertical housing acceptable and desirable.

\section{REFERENCES}

[1] Fullagar S., Pavlidis, A., Reid S., \& Lloyd K.,, "Living it up in the 'new world city': High-rise development and the promise of liveability", Annals of Leisure Research,Vol. 16, No. 4, pp. 280-296, 2013, DOI: https://doi.org/10.1080/11745398.2013.840946

[2] Dessy N. L. P., Paturusi S. A., Dwijendra N. K. A., \& Dewi 
N. K. A. "Development of Vertical Housing and the Effect of Bali People's Culture," International Conference, Phonom Penh, Cambodia, 4th-05th May, 2019, pp.16-32

[3] Jones P., "The shaping of form and structure in informal settlements: A case study of order and rules in Lebak Siliwangi, Bandung", J. Reg. City Plan, vol. 30, no. 1, page. 43-61, 2019, DOI: 10.5614/jpwk.2019.30.1.4

[4] Wassenberg F., Turkington, R., \& Van Kempen, R., "High-rise housing estates in Europe" in "High-rise housing in Europe: Current trends and future prospects", Housing and Urban Policy Studies 28, 2004, pp.1-282. URL: https://www.academia.edu/download/54340026/High_rise _housing_in_europe.

[5] Kalantari S., \& Shepley M., "Psychological and social impacts of high-rise buildings: a review of the post-occupancy evaluation literature", Housing studies, pp.1-30, 2020, DOI:

https://www.tandfonline.com/action/showCitFormats?doi= 10.1080/02673037.2020.1752630.

[6] Kaplan, S., "The restorative benefits of nature: Toward an integrative framework", environmental psychology, vol.15, no.3, pp.169-182, 1995.

[7] Amerio, A., Brambilla A., Morganti A., Aguglia, A., Bianchi D., Santi F., \& Capolongo S., "COVID-19 lockdown: housing built environment's effects on mental health", environmental research and public health, Vol.17, no16, pp.1-10, 2020, Doi:https://doi.org/10.3390/ijerph171 65973

[8] Gillis A. R., " High-rise housing and psychological strain”, Journal of Health and Social Behavior, Vol. 18, No. 4, pp. 418-431, 1997. URL: https://doi.org/10.2307/2955349

[9] Damari B., Shadpour, K., \& Roostamigooran N., "Healthy housing: A case study of intersectoral collaboration for better health", Medical journal of the Islamic Republic of Iran, vol. 32, No.64, pp.1-4, 2018. DOI: 10.14196/mjiri.32.64.

[10] Bonnefoy X., "Inadequate housing and health", environment and pollution, vol.30, No. 3-4, 2007. pp. 411-429. DOI: 10.1504/IJEP.2007.014819.
[11] Wells N. M., \& Moch A., "Housing and Mental Health: A Review of the Evidence and a Methodological and Conceptual Critique", social issues, Vol. 59, No. 3, 2003. pp.475-500, 2013. URL: https://is.muni.cz/el/fss/podzim20 11/HEN597/um/Readings_Env_Psy/Evans_Wells_Moch_ 2003.pdf.

[12] Gifford R., "The consequences of living in high-rise buildings", Architectural science review, vol.50, no.1, pp.2-17, 2007, DOI: http://dx.doi.org/10.3763/asre.2007.5 002 .

[13] Rollwagen, H., "The relationship between dwelling type and fear of crime", Environment and Behavior, vol.48, No.2, pp.365-387, 2016. DOI: https://doi.org/10.1177\%2F00139 16514540459

[14] Bin Abu Bakar M. E., \& King N. K., "Social Interaction and Third Space Relationship in Vertical Housing in Malaysia", International Transaction Journal of Engineering, Management, pp.1-10, 2010. URL: https://www.researchg ate.net/publication/337971568.

[15] Kootstra J., "Socially-oriented high-rise design in the Netherlands", MSc. Thesis submitted to University of groningen, 2020. URL:https://frw.studenttheses.ub.rug.nl/i d/eprint/3371.

[16] Wie I. W., \& Dewi J., "Space Configuration of Vertical Housing for Optimal Social Interaction Support", in Equity, Equality, And Justice In Urban Housing Development, KnE Social, August 2019, 421-443, DOI:10.18502/kss.v3i21.4985.

[17] Henry Steed., "The Interlace: A Landscape of Interlocking Polygons", pp.73-77, 2016. https://www.nparks.gov.sg/-/m edia/c

[18] Ami Mody, "The Interlace by OMA- A new direction for cities", Rethinking The future, URL: https://www.re-thinki ngthefuture.com.

[19] Ellie Stathaki., The Interlace by OMA / Ole Scheeren wins the inaugural Urban Habitat Award, https://www.wallpape r.com/(25 JUN 2014) 